\title{
'What makes you think Theology is a subject?'
}

\author{
Trevor Williams \\ trevor.williams@trinity.ox.ac.uk
}

\section{Abstract}

This article focuses on a topic, that is captured in a question that Richard Dawkins raised in 1993: 'What makes you think Theology is a subject?' My view is that this question is a symptom of how Theology is under attack from many quarters today - from the fearful believers who see it as a threat to their faith, to the secularists who see it as a threat to truth. Foremost among the opponents is Richard Dawkins. Outraged by a donation to Cambridge for the study of theology, he contrasts the usefulness of science with the uselessness of Theology. The question though, is: What is Theology? In this chapter, I draw a distinction between Confessional Theology and Critical Theology. By Confessional Theology I mean the affirmation of an exclusive point of reference by which all other claims to authority and knowledge are judged. Thus Christians 'confess Jesus Christ is Lord', and Confessional Theology is the rational articulation of the Christian Faith from within the circle of Faith the convictions, experiences, and hopes grounded in the story of Jesus and characterized by commitment and involvement. However, there are ways in which both scientists and theologians, and the two types of Theology, can go wrong.

Keywords: Theology, Richard Dawkins, science, Confessional Theology, Critical Theology, Christian Faith

It's not so very long since proposing Theology as an academic subject could provoke passionate indignation. To quote, 
What has Theology ever said that was of the smallest use to anybody? ... If all the achievements of theologians were wiped out tomorrow, would anyone notice the smallest difference? ... Even the bad achievements of science ... work. The achievements of theologians don't do anything, don't affect anything, don't achieve anything, don't even mean anything. What makes you think 'theology' is a subject at all? (Dawkins 1993).

Before they run for cover Theology teachers may justifiably pause to examine more closely this outburst in which we may recognize the familiar voice of Professor Richard Dawkins. On this occasion he was reacting to the news of a recent endowment of a lecturership in Theology and Natural Sciences at Cambridge. But he speaks for many, as the continuing debate has shown, though its failure to distinguish between religion and theology, and different kinds of theology leaves gaps that need to be filled. I suspect that there may still be some in this University (i.e. Oxford), who think much the same way as Professor Dawkins. At worst they think Theology is a meaningless or even harmful non-subject, which ought to be put down, or at best left in an outhouse for a few odd people to study and teach for old time's sake.

The issue I want to address now is Theology at Oxford. For a start I would like to draw a distinction between 'Confessional theology' and 'Critical theology. They are certainly not unrelated, yet distinct. By contrasting confessional and critical theology I do not wish to imply that the latter is rational and the former is not, but that they both use reason but in different ways. 'Confessional Theology' on the one hand focuses on a particular object of commitment and devotion - Jesus Christ in the case of Christianity. Christians are those who 'confess' 'Jesus Christ as Lord'. Confessional Theology employs reason to give coherent expression to the convictions, experiences, and hopes that are grounded, in the story of Jesus Nazareth, and which give shape to Christian life. It is a task undertaken in the belief that that story points to the mysterious reality on which the ultimate meaning and goal, not only of human existence but of the cosmos, depends; not only so, but that through that story and the person it is about, a way is opened into relationship with that ultimate reality that empowers all life.

The character of confessional theology is commitment and involvement. Maybe that is why it can spread such alarm in a secular 


\section{Trevor Williams}

society, where, though ideals of freedom of thought and speech are cherished, commitment of any kind is often suspect, and where religious commitment above all is too easily assumed to mean blind fanaticism.

In contrast to Confessional Theology, Critical Theology is characterized by detachment rather than by commitment. As such it is the often unrecognised ally of philosophy and science - at their best in being rationally motivated - in its championing of free thought and speech, in its readiness to subject every belief, tradition, document, formulation, institution, experience, and conviction to critical examination. It will not swallow scientific theories uncritically, but will acknowledge the valid insights of the physical, biological, and human sciences. In doing so, Critical Theology shares with scientists a passionate concern for truth. So what's gone wrong? Why are we at odds? I suspect we are both to blame. Christians, and that can include theologians, profess to worship the God of truth. Therefore they should have nothing to fear from truth from whatever quarter it is disclosed. So why they are so frightened so much of the time?! One reason may be the fact that Christians, like everyone else, have to use the language and ideas of their age to express their convictions and make sense of their beliefs. The danger lies in mistaking the ship for its cargo, the provisional conceptual framework for the ultimate truth it carries.

When science in its search for truth, not simply for things that work, shatters the inherited framework, a fearful Christian faith digs its heels in, mistakes itself for science, and ends up as bad theology or unworkable science, or both - unworkable, because untrue. It is then all too likely to mistake its obstinate resistance to new insight, for faith, and to dismiss openness to new understanding, as surrender to trendy fashion. A theology reacting in this way betrays itself and deserves its scornful repudiation.

Of course; it's unfair to criticise the abstraction 'theology' for every misconception held by theologians down the centuries about evolution, or the origin of the universe or causes of disease, when there was no-one at the time able to offer plausible alternative views, and scientists themselves hadn't even evolved! It is fair, though, to criticize those who cling to ancient misconceptions in the name of the Creator in the face of what scientists have discovered about the creation - discoveries validated in many cases because they have led to things that work.

But if theologians have at times gone wrong, so have scientists some at least, including those secularists who look to science and to human 
reason alone as the way, the truth and the life. That is one fault for a start, when science mistakes itself for theology and pronounces upon ultimate questions far beyond the remit of its own methodology, as, for example, Nobel Prize winner, Jacques Monod did at the end of Chance and Necessity (1971). That is when science becomes pseudo religion. In its enthusiasm to consign heretics to the flames, or at least the rubbish dump, it is sometimes on a par with intolerant, triumphalist religion at its worst.

Scientists are at fault too if they mistake what theology is and castigate it for not being natural science - it isn't and isn't meant to be. They are at fault again if they fail to distinguish between confessional theology, which rests on shared axioms of faith, and has its place in a community of faith, and critical theology, which is willing to examine and test even its own axioms in the open arena of intellectual inquiry. They are at fault if they lazily mock out of date theology while celebrating the latest findings of science, or if they make no effort to distinguish fearful or bad theology from good theology. Good and bad theology ought to be as carefully distinguished as good and bad science.

One of the responses to the original letter I quoted came from Nicos Mouzilis (1993), Professor of Sociology at the London School of Economics. He wrote,

... To compare science to theology in such a manner is like trying

to prove that a hammer is more effective in making chairs than a lily.

He continues,

This constitutes an excellent example of how intelligent people can portray a total lack of imagination when they, tread into a discipline that is qualitatively different from their own.

But then the question is, What is qualitatively different about theology? What is it meant to be or do? Here I approach it as a University discipline, but also as more than that. To go back to its roots, Theology is the study of theos, God. Before the critics run off complaining 'There's no such thing as God and therefore no such subject as Theology', I beg them to pause and hear two pleas in its defence. 
First I would say, whether God is real or not, the fact remains that belief in God, more particularly, the Christian God, has shaped our history, our culture, our values. A critical examination of the origins and development of Christianity is a valid undertaking in any University, not least at Oxford.

There's force in this argument; it's the reason why quite a few people who are not religiously committed undertake the study of Theology. The defence of Theology as virtually a branch of history was a useful survival strategy in the heyday of logical positivism. 'God-talk' might be deemed strictly meaningless, but no one could deny that 'God' had been 'talked', and the critical historical, scientific investigation of when and how this had been going on could pass muster even in a secular university. Recognition of the importance of this wider context explains why the Faculty of Theology at Oxford has recently changed its title to the 'Faculty of Theology and Religion'. It explains why at the same time, this approach gave scope for the religious minded not only to acquire the intellectual skills proper to any Arts degree, but to pick up quite a bit of what they needed to know as the background and basis of the Christian faith.

But the weakness of this defence lies precisely in its reductionism, in the danger of categorizing Theology as just one subject among others, and very much a minority subject, which can take its place alongside other disciplines. This would be a disaster because though it is another arts subject, it is qualitatively different.

Here I make my second plea. Theology is not just history; it answers to something which other subjects do not answer to. Whether we think God exists or not, human beings do have a sense and taste and yearning for the infinite. They do ask why there is something and not nothing, and what is the meaning and purpose of life. Theology is the context in which such questions are raised and addressed, whether from a confessional or critical point of view. Each has its own perspective: both stand to gain from respecting each other rather than aiming to dominate or eliminate the other.

Not long ago a young woman in her first year said to me 'I can't understand why so many people aren't aware of their spirituality!' Or is the problem rather that so many people dare not admit their spirituality? because it's unfashionable, perhaps, or because they have been taught by those who are sure that nothing can be real or true which is not open to laboratory experimentation, or simply because it has been hitched to some folkway 
thinking - an old man in the sky, for instance - so that if that goes, it must go too. But if the yearning for spiritual reality, for depth in life, is there, but denies a transcendent perception as its object, it is all too likely to break out in alternative bizarre and even dangerous ideological forms.

Cults are one example, especially when they isolate themselves from the world, as in the tragedy at Waco (cf. Docherty 2001). Modern day pilgrimages are another, like those to Elvis Presley's house, with its candlelight vigil on the anniversary of his death. David Lodge in the Sunday Times saw this as 'an expression of a human longing for transcendence ... which if diverted from orthodox religious traditions, will manifest itself in heterodox or secularized forms'. Such longing of course, neither proves nor disproves the reality of the object of longing.

Many of these secularized alternatives to religious traditions are relatively harmless, but many are not. There are various movements today which witness to some valid truth or good, but when they attempt to fill completely with their partial truths the spiritual vacuum left by God's expulsion, they become unhelpful, or even damaging, if not violent and destructive. One might think here of certain Animal Rights or antiabortion, or ecology extremists. Whatever truth or value they stand for, often courageously, they betray, when they claim to be or to have the absolute truth.

There will be more causes like these and they will not be harmless. The shallowness of individualist consumerist culture will definitely in future lead more and more people to search for depth and meaning, for something worthy of total sacrifice and commitment. Without forms of worthy social interaction, and caring assistance, they might become victims of a variety of forms of powerful absolutes, which may not serve their best interests, nor that of community, society, or the world at large. So, in whose name can false absolutes be exposed and judged? Science has no means of fending them off. Indeed, it often helps create them. A science that worked, and produced some of the most significant electronic, mechanical, and industrial advances our world has ever seen, served the false gods that produced Auschwitz-Birkenau with its cynical slogan of 'Arbeit macht frei'. Science as such cannot expose or refute false gods, any more than theology can unravel DNA or explain the Big Bang. Their tasks are different, and remain different even if they meet in some exceptional individuals. 
It might still be argued that we do not need Theology to fend off false absolutes, because critical philosophy since the Enlightenment, has succeeded very well in doing this by relativizing improper claims to final truth and value, both inside and outside Christianity. I gladly give credit where it's due, but though relativism is an excellent weapon against false gods, it offers no answer to the persistent question of transcendence, and no pathway towards a deeper understanding in which all life and experience may be comprehended. If God-talk is in fact transcendence talk or depth talk, then the loss of all God-talk, true or false, under the dead hand of relativism means the loss of transcendence, the loss of depth, the trivialisation of everything because nothing is allowed to count more than anything else, which means in the end nothing truly counts at all.

Relativism itself can become a false god, an absolute, but absolute relativism is not only difficult, but impossible, a contradiction in terms. It merely serves as a cloak under which hidden absolutes lurk with more or less capacity for good or ill, depending on the unacknowledged influences that have shaped them. In a Christian society these may in some measure have worked for good, though certainly not to perfection! In a post-Christian society we cannot assume that hidden absolutes will be shaped by goodness or work for humanity's good. Rather, these absolutes themselves, especially the hidden absolutes, in conflict, should be put under scrutiny and collectively, and interactively engaged and responsively studied.

Hidden absolutes are in fact the support and privilege of individualism. Communities need the support of shared absolutes and ideals, as our society is just beginning to realise in a bit of a panic. In the wider world, the collapse of Communism as the key to wholeness and meaning in communal life has left the field open not just to individualism, as the West naively hoped, but to other communal absolutes, from street gangs to terrorist movements to horrific nationalisms. Whether we believe God exists or not, there is a spiritual energy that flows through human life, which, if it flows into the wrong channels can be appallingly destructive. Just wishing it wasn't there or ignoring it, or, even trying to crush it through force, will not remove or tame it.

Oxford colleges are not yet the places where the worst turmoil is likely to be witnessed, but the young men and women being educated there 
will go into a post cold war world which is potentially even more dangerous - where they may experience the collapse of values and the fragmentation of society, or alternatively, be met with powerful claims to their lives and allegiance, where either way they are likely to be involved in decisions or in actions provoked by the pursuit of transcendence or the claims of professed absolutes, or by the random violence of those who have lost hope.

Critical theology is the context in which questions of the meaning of transcendence, the experience of depth, and the claims of the ultimate are raised, talked about, tested and explored. As a subject it certainly requires many skills and a lot of basic spadework in history, languages, literature, philosophy, and psychology and sociology. But, it does not stop there, because human beings do not stop there. They ask, What does it mean for me? Where do I go from here?

The best defence against false, fraudulent, dangerous theologies is not science, or even psychology or sociology, but a critical, historically aware, questioning theology which engages with the world we all inhabit and does not hide from it, but which also takes spiritual yearning seriously and does not simply try to explain it away or dismiss it with contempt, or abandon all hope of moving nearer to its object.

Critical theology in the Christian tradition dares to face up to questions of ultimacy, and to examine its own foundations ruthlessly, more ruthlessly perhaps than any other discipline. It can be assisted in this task by those who are not personally committed to the Christian faith, and by those who stand in different traditions of it. Despite the traditional hostility to theology of both kinds, Confessional and Critical, in some quarters, exciting new ways of doing Theology at Oxford are opening the door to theologians of either sex or of any denomination or none. It would be tragic if colleges chose this moment to close their doors, whether as a result of financial worries - which we all face - or simply due to out-of-date misguided ideas over what Theology is.

As an example of wrong thinking on this score, I can mention a remark once made to an undergraduate reading Philosophy and Theology. She told me that her philosophy tutor had asked her, 'How can you bear to do philosophy alongside a subject which doesn't let you think for yourself?' That remark betrays culpable ignorance, even if there do 


\section{Trevor Williams}

exist some kinds of so-called theology elsewhere that might incur the charge. I do not want to over-romanticise theology as a subject. Like any other it is hard academic grind much of the time, but it does make you think, and it makes you think at some point about what is of ultimate importance. That is its distinctive quality.

The alternative to bad theologies is not no theology, but good, critical theology, because the questions and issues will not go away. And this country, and the world at large, needs good Theology, not just in its Churches, but in its universities, schools and public life. And, what would an academic curriculum look like that left no room for human beings to engage with the deepest issues they encounter? Where an ephemeral Utilitarianism had driven out all talk of the spiritual and eternal? There need to be undergraduate and graduate theologians not only engaging with the subject, but in their colleges testing and being tested by their friends in every other subject, testing every claim to ultimacy in relation to every discovery of science, and against every new perception of truth arising through the human mind or spirit. Dare we add that the same should be happening in every Senior Common Room too?

If that happens in our various educational institutions, then not only our theologians but all our students may find more point and meaning in what they are doing here in Oxford and be better equipped to unmask and resist evil, and to recognise and bring good to effect, which is a far cry from seeing religion as merely a handmaid to middle-class morality. It is time theology came out of the closet into which an impoverished secularism and scientism have tried to squeeze it, and where it has sometimes tried to hide itself; it should rather be given and be ready to accept its qualitatively unique place in a modern university.

It may be that out of the study, analysis, and critical questioning of the Christian tradition in particular, some people will arrive at the conviction that it is the bearer of the truth that can satisfy the deepest yearning of the human spirit and heal its wounds. They may want to go on to try and articulate its meaning and implications in terms of Confessional Theology, whether inside or outside the University. But Confessional Theology can never afford to leave Critical Theology behind, because without it, Theology isolated from the world, sinks into superstition. 
Confessional Theology itself does not claim perfect knowledge, nor does it peddle instant certainties. Rather, it springs from the faith that has the courage to accept doubts rather than repress them. Repressed doubt is the high road to fanaticism. Christian faith by contrast is open to new truth and new life wherever it is manifested. It shares with science a faith in the rational structure of reality, but believes that the life giving truth about ourselves and our world flows ultimately through and from the person of Jesus Christ, in a way that does seem to work and achieve quite a lot, and is not at war with the truths revealed by science. Those who believe that Jesus Christ is the way, the truth and the life, cannot easily suppose that those who are passionately concerned for truth, are far from God.

\section{References}

Dawkins, R. 1993. Scientific versus Theological Knowledge. Independent 20 March 1993. Available at:

https://www.independent.co.uk/voices/letter-scientific-versustheological-knowledge-1498837.html

Docherty, J.S. 2001. Learning Lessons from Waco. Syracuse: Syracuse University Press.

Monod, J. 1971. Chance and Necessity: An Essay on the Natural Philosophy of Modern Biology. New York, Alfred A. Knopf.

Mouzelis, N.P. 1993. Science and Theology: Material and Spiritual Questions that are Worlds Apart. Independent 23 March 1993. Available at: https://www.independent.co.uk/voices/letter-science-andtheology-material-and-spiritual-questions-that-are-worlds-apart$\underline{1499382 . h t m l}$

Trevor Williams

Trinity College

Oxford

trevor.williams@trinity.ox.ac.uk 